\title{
Purinergic Signaling Promotes Proliferation of Adult Mouse Subventricular Zone Cells
}

\author{
Satoshi Suyama, ${ }^{1}$ Takehiko Sunabori, ${ }^{1,2}$ Hiroaki Kanki, ${ }^{1}$ Kazunobu Sawamoto, ${ }^{3}$ Christian Gachet, ${ }^{4}$ Schuichi Koizumi, ${ }^{5}$ \\ and Hideyuki Okano ${ }^{1}$ \\ ${ }^{1}$ Department of Physiology, Keio University School of Medicine, Tokyo 160-8582, Japan, ${ }^{2}$ Department of Cell Biology and Neuroscience, Juntendo \\ University Graduate School of Medicine, Tokyo 113-0033, Japan, ${ }^{3}$ Department of Developmental and Regenerative Biology, Nagoya City University \\ Graduate School of Medical Sciences, Nagoya, Aichi 467-8601, Japan, ${ }^{4}$ UMR_S949 INSERM, Université de Strasbourg, Etablissement Français du Sang- \\ Alsace, 67065, Strasbourg Cedex, France, and ${ }^{5}$ Department of Pharmacology, Interdisciplinary Graduate School of Medicine and Engineering, University of \\ Yamanashi, Yamanashi 409-3898, Japan
}

In adult mammalian brains, neural stem cells (NSCs) exist in the subventricular zone (SVZ), where persistent neurogenesis continues throughout life. Those NSCs produce neuroblasts that migrate into the olfactory bulb via formation of transit-amplifying cells, which are committed precursor cells of the neuronal lineage. In this SVZ niche, cell-cell communications conducted by diffusible factors as well as physical cell-cell contacts are important for the regulation of the proliferation and fate determination of NSCs. Previous studies have suggested that extracellular purinergic signaling, which is mediated by purine compounds such as ATP, plays important roles in cell-cell communication in the CNS. Purinergic signaling also promotes the proliferation of adult NSCs in vitro. However, the in vivo roles of purinergic signaling in the neurogenic niche still remain unknown. In this study, ATP infusion into the lateral ventricle of the mouse brain resulted in an increase in the numbers of rapidly dividing cells and Mash1-positive transit-amplifying cells (Type C cells) in the SVZ. Mash1-positive cells express the P2Y1 purinergic signaling receptor and infusion of the P2Y1 receptor-specific antagonist MRS2179 decreased the number of rapidly dividing bromodeoxyuridine (BrdU)-positive cells and Type C cells. Moreover, a 17\% reduction of rapidly dividing BrdU-positive cells and a 19\% reduction of Mash1-positive cells were observed in P2Y1 knock-out mice. Together, these results suggest that purinergic signaling promotes the proliferation of rapidly dividing cells and transit-amplifying cells, in the SVZ niche through the $\mathrm{P} 2 \mathrm{Y} 1$ receptor.

\section{Introduction}

Neurogenesis persists in two germinal regions of the adult mammalian brain: the subventricular zone (SVZ) of the lateral ventricle (LV; Alvarez-Buylla and Garcia-Verdugo, 2002) and the subgranular zone (SGZ) in the hippocampal dentate gyrus (Okano, 2002; Kempermann et al., 2004; Okano and Sawamoto, 2008). These neurogenic niches provide microenvironments that regulate the proliferation and differentiation of neural stem cells (Spradling et al., 2001; Song et al., 2002; Fuchs et al., 2004; Shen et al., 2004, 2008; Tavazoie et al., 2008). In the SVZ niche, stem cell astrocytes (Type B cells) divide slowly to generate neuroblasts

Received Aug. 3, 2011; revised May 18, 2012; accepted May 23, 2012.

Author contributions: S.S., T.S., and H.O. designed research;S.S. performed research; S.S., C.G., and S.K. contributed unpublished reagents/analytic tools; S.S. analyzed data; S.S., T.S., H.K., K.S., S.K., and H.O. wrote the paper.

This work was supported by grants from the Ministry of Education, Culture, Sports, Science and Technology (MEXT), the Japan Science and Technology Corporation (JST), and the Japan Society for the Promotion of Science (JSPS) through the "Funding Program for World-leading Innovative R\&D on Science and Technology (FIRST Program) to H.O.; by a Keio University grant-in-aid for encouragement of young medical scientists; by a grant-in-aid from the Global COE (Centers of Excellence) Program of MEXT, Japan to Keio University; and by the Japan Society for the Promotion of Science Fellows to S.S., and a Grant-in-Aid for the Global COE Program at Keio University. We thank members of the 0 kano laboratory for helpful advice on this study.

The authors declare no competing financial interests.

Correspondence should be addressed to Hideyuki Okano, Department of Physiology, Keio University School of Medicine, Shinjuku-ku, Tokyo 160-8582, Japan. E-mail: hidokano@a2.keio.jp.

DOl:10.1523/JNEUROSCI.4001-11.2012

Copyright $\odot 2012$ the authors $\quad 0270-6474 / 12 / 329238-10 \$ 15.00 / 0$
(Type A cells) via rapidly dividing transit-amplifying cell intermediates (Type C cells) (Doetsch et al., 1999). Cell proliferation and neurogenesis within the niche are regulated by spatially and temporally coordinated cues, including cell-cell communication involving the extracellular matrix and diffusible factors such as FGF-2 and EGF (Riquelme et al., 2008).

Purine nucleotides, particularly ATP and ADP, are a class of metabolites that act as extracellular signals via $\mathrm{P} 2 / \mathrm{ATP}$ receptors: the ionotropic P2X and metabotropic G-protein-coupled P2Y classes of receptors (Burnstock, 1996; Ralevic and Burnstock, 1998). In the CNS, purinergic signaling is critical for a variety of cellular functions including proliferation, migration, and intercellular communication (Franke et al., 2006; Zimmermann, 2006; Maria et al., 2008). Purinergic signaling has also been implicated in developmental and adult neurogenesis. In the fetal brain, for instance, ATP promotes the proliferation of radial glia, which are neural stem cells in the fetal brain, through the P2Y1 receptor. In contrast, P2Y1 antagonists such as suramin and MRS2179 inhibit the proliferation of radial glia (Weissman et al., 2004).

ATP-mediated purinergic signaling through the $\mathrm{P} 2 \mathrm{Y}$ receptor also promotes the expansion of neurospheres derived from fetal or adult brains. $\mathrm{P} 2 \mathrm{Y} 1$ and $\mathrm{P} 2 \mathrm{Y} 2$ receptors regulate the expansion of adult SVZ-derived neurospheres by mediating calcium release from the endoplasmic reticulum to the cytoplasm. Thus, agonists for these receptors induce calcium release, which in turn func- 


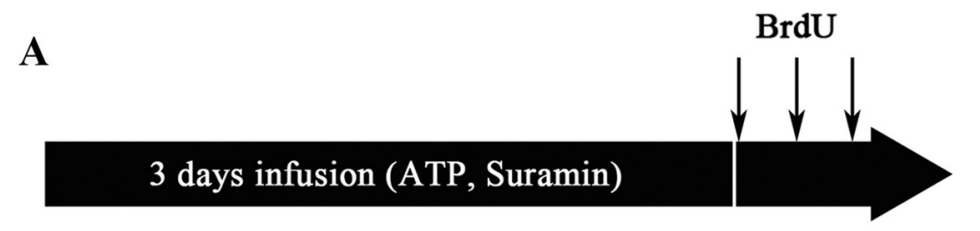

$\mathbf{B}$
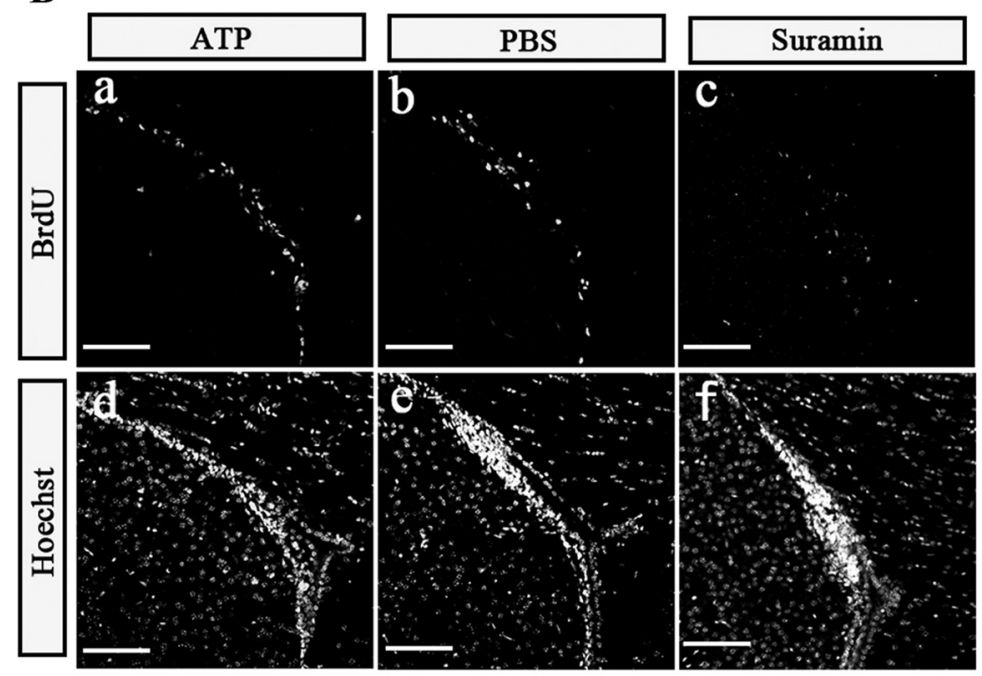

C

BrdU

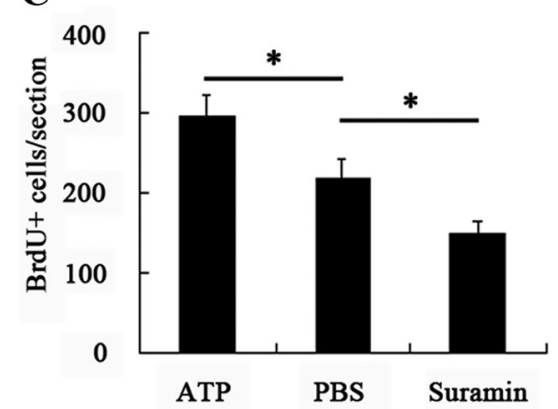

Figure 1. Short-term labeling: $\mathrm{BrdU}^{+}$cells are increased by purinergic signaling in adult mouse SVZ.A, Scheme of infusion and short-term BrdU administration. $\boldsymbol{B}$, BrdU-labeled cells in the contralateral SVZ $(\boldsymbol{a}-\boldsymbol{c})$ and Hoechst staining of the same sections $(\boldsymbol{d}-\boldsymbol{f})$. The LVs of mice were continually infused with $\operatorname{ATP}(\boldsymbol{a}, \boldsymbol{d}), \operatorname{PBS}(\boldsymbol{b}, \boldsymbol{e})$, or suramin $(\boldsymbol{c}, \boldsymbol{f})$ for $3 \mathrm{~d}$, and then injected with BrdU every $200 \mathrm{~min}$ for $10 \mathrm{~h}$ before they were killed. Scale bars, $100 \mu \mathrm{m}$. C, Quantitative analysis of BrdU ${ }^{+}$cells in the contralateral SVZ. Mice were continually infused with ATP, PBS, or suramin into the LV for $3 \mathrm{~d}$, and then injected with BrdU every $200 \mathrm{~min}$ for $10 \mathrm{~h}$ before they were killed. Values represent the mean \pm SEM. ${ }^{*} p<0.05$ versus PBS-infused brain ( $n=6$ per group).

tions as a mitogen in adult mouse SVZ-derived neurospheres (Mishra et al., 2006). In addition, previous reports suggest the expression of $\mathrm{P} 2 \mathrm{Y} 1, \mathrm{P} 2 \mathrm{Y} 2$, and/or $\mathrm{P} 2 \mathrm{Y} 4$ receptors in the lateral wall of the adult mouse LV (Mishra et al., 2006; Lin et al., 2007). Therefore, ATP-mediated purinergic signaling has been speculated to play important roles in adult neurogenesis in the SVZ, especially in cell proliferation. However, the in vivo roles of ATPmediated purinergic signaling in the adult SVZ have yet to be determined. We investigated in this study the in vivo functions of ATP-mediated purinergic signaling in neurogenesis in the adult SVZ.

\section{Materials and Methods}

Animals. Adult male CD-1 mice ( 8 weeks old) and C57BL/6 mice (8 weeks old) were purchased from Japan SLC. P2Y1 knock-out mice (C57BL/6 background) have been previously described (Léon et al., 1999). The animals were maintained on a $12 \mathrm{~h}$ light/dark cycle with unlimited access to food and water. All animal-related procedures were performed in accordance with the Keio University guidelines and regulations.

Infusion into the SVZ. ATP $\left(2 \mu \mathrm{g} \cdot \mathrm{kg}^{-1} \cdot \mathrm{h}^{-1}\right)$, $\operatorname{suramin}\left(24 \mu \mathrm{g} \cdot \mathrm{kg}^{-1} \cdot \mathrm{h}^{-1}\right)$, or MRS2179 $(6 \mu \mathrm{g}$ $\left.\cdot \mathrm{kg}^{-1} \cdot \mathrm{h}^{-1}\right)$ dissolved in PBS (137 $\mathrm{mm} \mathrm{NaCl}, 2.7$

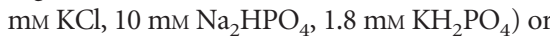
vehicle alone was infused into the lateral ventricle (0.2 $\mathrm{mm}$ posterior, $0.9 \mathrm{~mm}$ lateral to bregma and at a depth of $2.1 \mathrm{~mm}$ from the scalp) at $0.5 \mu \mathrm{l} / \mathrm{h}$ for the stated number of days using the Brain Infusion Kit 3 (Alzet) and an osmotic pump (Alzet).

Bromodeoxyuridine labeling. For short-term labeling, mice received intraperitoneal injections of bromodeoxyuridine (BrdU; $50 \mathrm{mg} / \mathrm{kg}$ in PBS) every $200 \mathrm{~min}$ for $10 \mathrm{~h}$ after the intraventricular infusion and were killed $200 \mathrm{~min}$ after the last injection. For long-term labeling, $1 \mathrm{mg} / \mathrm{ml} \mathrm{BrdU}$ was administered to mice via the drinking water for 2 weeks (Doetsch et al., 1999; Johansson et al., 1999; Sakaguchi et al., 2006; Imaizumi et al., 2011). Following the BrdU administration, normal water was then provided for 1 week as " $7 \mathrm{~d}$ washout time." Mice were infused with ATP, ATP antagonist, or PBS for $7 \mathrm{~d}$ after the switch from BrdU to normal water and then killed immediately. The brains were then processed for immunohistochemistry.

Reverse transcriptase PCR analysis. Total RNA was isolated from the SVZ using TRIzol reagent (Invitrogen). The RNA was processed with the RNeasy Mini Kit (Qiagen), and then treated with DNase I. cDNA was synthesized with Superscript 3 (Invitrogen) using oligo-d(T) ${ }_{12-18}$ primers. RNA isolation and cDNA production were previously described (Okada et al., 2004). P2Y1, $\mathrm{P} 2 \mathrm{Y} 2$ and P2Y4 primer sets were previously described (Mishra et al., 2006) (P2Y1F: 5'-CCTG CGAAGTTATTTCATCTA-3';P2Y1R:5'-GTTG AGACTTGCTAGACCTCT-3';P2Y2F:5'-TCTG CTTCCTGCCTTTCCAC-3'; P2Y2R: 5' ${ }^{\prime}$ TCCG TCTTGAGTCGTCACTG-3'; P2Y4F: 5'-AGCC CAAGTTCTGGAGATGGTG-3'; P2Y4R: $5^{\prime}$ GGTGGTTCCATTGGCATTGG-3'). PCR was performed in a volume of $25 \mu$ l using the KOD Plus kit (Toyobo) according to the manufacturer's instructions. The PCR included 28 cycles with an annealing temperature of $55^{\circ} \mathrm{C}$.

Real-time PCR analysis. Total RNA purified from the SVZ and cortex was reversetranscribed to cDNA (100-200 ng). The amounts of the PCR products corresponding to the P2Y1, P2Y2, and $\mathrm{P} 2 \mathrm{Y} 4$ receptors were normalized to $\beta$-actin. The P2Y1, P2Y2, or P2Y4 primer sets used were as follows: P2Y1qF: 5'-AGGCCACGCGCTCTCCAAAAGA-3'; P2Y1qR: 5'-ACCTTGCAACCCGGGACCTTCA-3'; P2Y2qF: 5'-GCGGCTGCTCAAACCGGCTTAT-3'; P2Y2qR: 5' -AAGGCAGGAAGCAGAGGGCGAA-3'; P2Y4qF: 5'-ACTCATGGCCCGGCGACTGTAT-3'; P2Y4qR: 5' -GCGGGTGATGTGGAAAGGCACAA-3'. The $\beta$-actin primer set was previously described (Okada et al., 2004). Real-time PCR was performed in a final volume of $25 \mu \mathrm{l}$ using SYBR Premix Ex Taq (Takara) according to the manufacturer's instructions with a Mx3000P cycler (Stratagene). The PCR included 45 cycles with an annealing temperature of $60^{\circ} \mathrm{C}$.

Immunoblotting. SVZs were dissected and homogenized in MAPKlysis buffer (containing, in mm: 10 Tris- $\mathrm{HCl}, \mathrm{pH}$ 7.6, $50 \mathrm{NaCl}, 30$ $\mathrm{Na}_{3} \mathrm{PO}_{4}, 50 \mathrm{NaF}, 20 \beta$-glycerophosphoric acid, $1 \%$ Triton X-100). Protein concentrations were determined using the BCA assay kit (Thermo Fisher Scientific) and 20 or $30 \mu \mathrm{g}$ of protein were separated by SDSPAGE and then electroblotted onto polyvinylidene difluoride mem- 

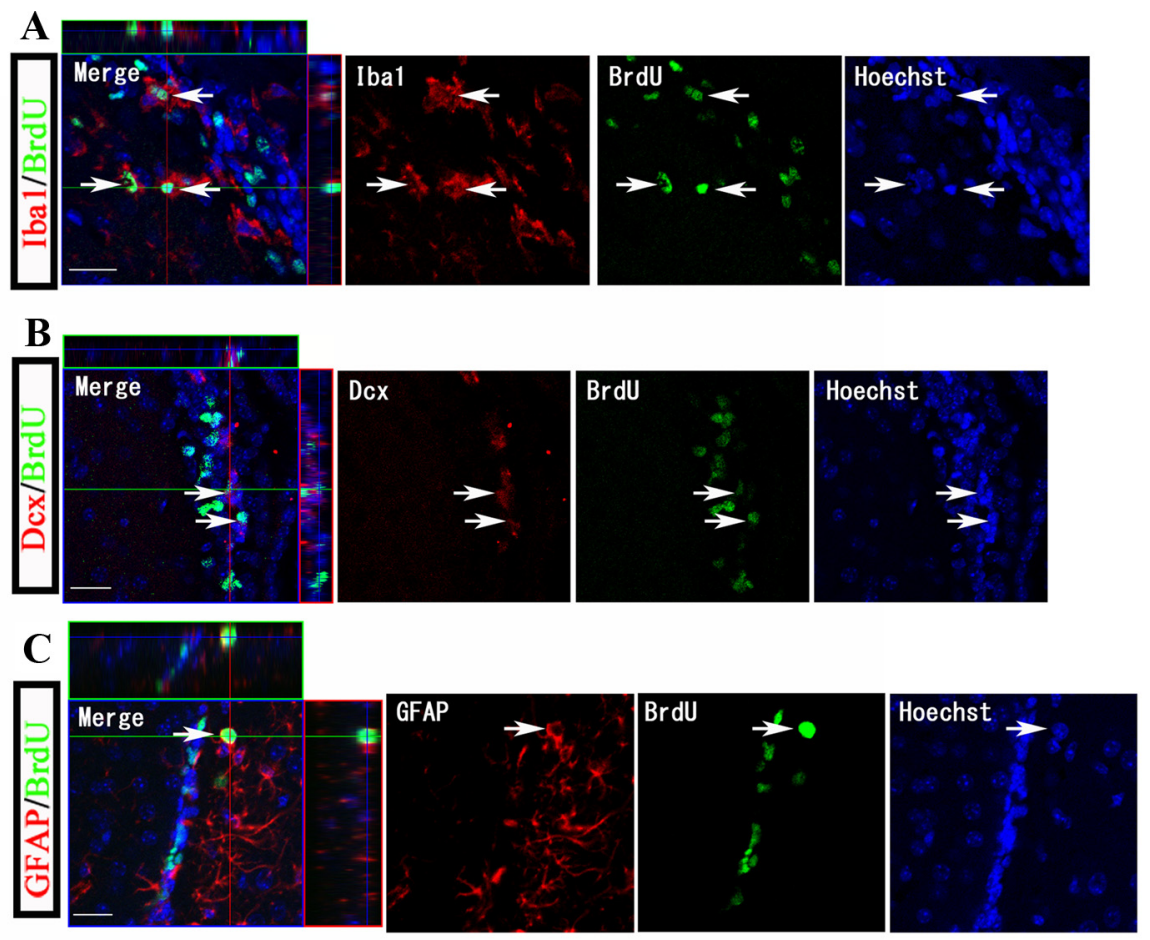

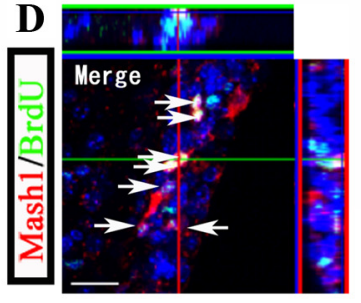

$\mathbf{E}$

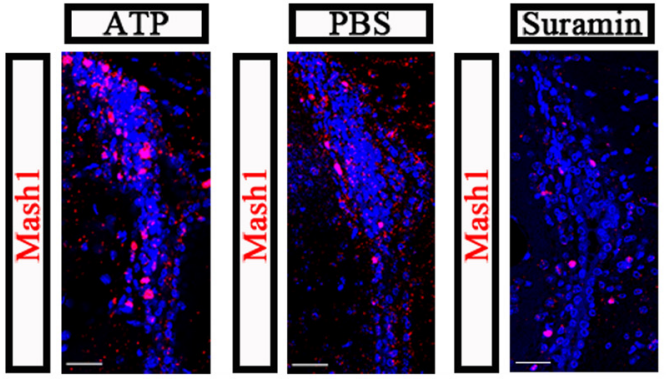

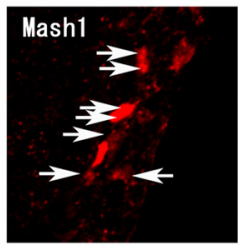

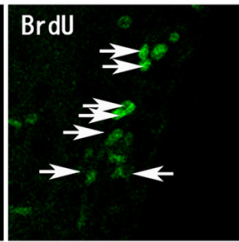

F

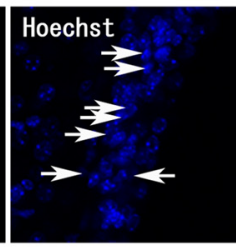

Mash1

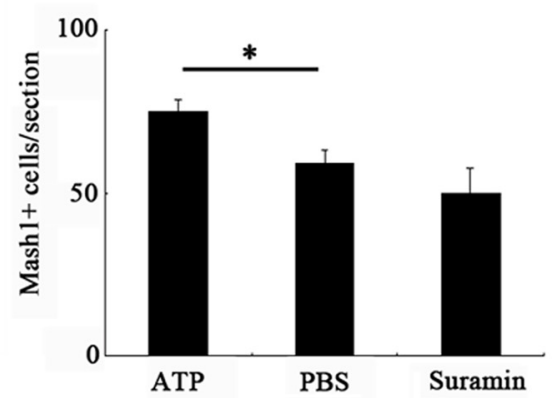

Figure 2. ATP promotes proliferation of Type ( cells in the adult mouse SVZ. $\boldsymbol{A}-\boldsymbol{D}$, Immunohistochemical analysis of BrdU ${ }^{+}$cells in ATP-infused mice using antibodies against Iba1 (A), Dcx (B), GFAP (C), and Mash1 (D). Mice were continually infused with ATP, PBS, or suramin into the LV for $3 \mathrm{~d}$, and then injected with BrdU every 200 min for $10 \mathrm{~h}$ before they were killed. Immunohistochemical analysis was performed by counting BrdU ${ }^{+}$cells in the contralateral SVZ. Colocalization of each cell marker with BrdU was assessed by determining the percentage of 821 BrdU ${ }^{+}$cells that were also lba ${ }^{+}(\boldsymbol{A})$, the percentage of $1240 \mathrm{BrdU}^{+}$cells that were also $\mathrm{Dcx}{ }^{+}(\boldsymbol{B})$, the percentage of $1215 \mathrm{BrdU}^{+}$cells that were also $\mathrm{GFAP}^{+}(\boldsymbol{C})$, and the percentage of $875 \mathrm{BrdU}{ }^{+}$cells that were also Mash $1^{+}$(D). Scale bars, $40 \mu \mathrm{m}$ ( $n=3$ per group). E, Mash1-labeled cells in the contralateral SVZ. Mice were treated with continual infusion of ATP, PBS, or suramin into the LV for $3 \mathrm{~d}$, followed

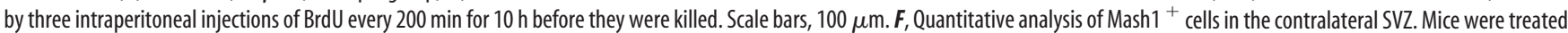
with continual infusion of ATP, PBS, or suramin into the LV for $3 \mathrm{~d}$, followed by three intraperitoneal injections of BrdU every $200 \mathrm{~min}$ for $10 \mathrm{~h}$ before they were killed. Values represent the mean \pm SEM. ${ }^{*} p<0.05$ vs PBS-infused brain ( $n=6$ per group).

branes. The membranes were incubated with rabbit polyclonal antibodies directed against the P2Y1 receptor (1:1000; MBL International) or mouse polyclonal antibodies directed against $\alpha$-tubulin (1: 5000; Sigma). Signals were detected with the luminescence assay kit (GE Healthcare, Thermo Fisher Scientific).

Immunohistochemistry. Brains were perfusion-fixed with $4 \%$ paraformaldehyde, followed by an overnight postfixation in the same fixative at $4^{\circ} \mathrm{C}$. Sections $(50 \mu \mathrm{m})$ were prepared on the next day with a Vibratome (VT1000S; Leica). After three rinses in PBS, sections were incubated either in ethanol/acetone (50:50) for $30 \mathrm{~min}$ at $-20^{\circ} \mathrm{C}$ [for GFAP (glial fibrillary acidic protein)] or in $2 \mathrm{~N} \mathrm{HCl}$ for $30 \mathrm{~min}$ (for BrdU). The sections were then incubated for $1 \mathrm{~h}$ in the TNB (Tris-NaCl blocking) solution (Vector Laboratories), then overnight with one of the primary antibodies, followed by a $1 \mathrm{~h}$ incubation at room temperature with HRPconjugated secondary antibody (1:250) or Alexa Fluor-conjugated secondary antibody (1:250; Invitrogen). HRP-conjugated antibodies were visualized using TSA (PerkinElmer Life and Analytical Sciences). The following primary antibodies were used in this study: mouse monoclonal 
A

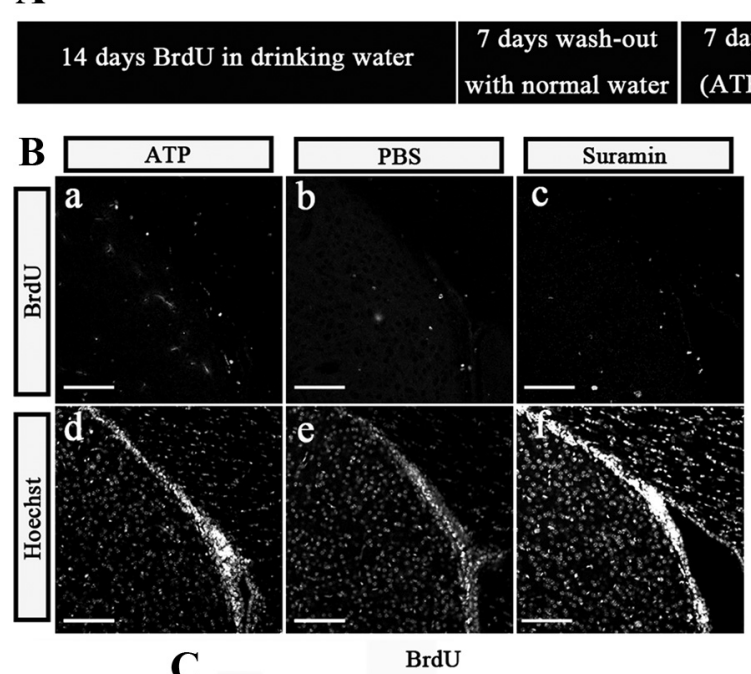

C

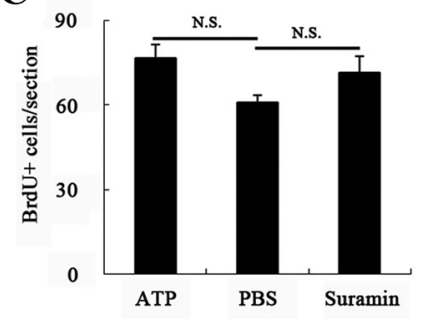

Figure 3. Long-term labeling: BrdU ${ }^{+}$cells were not increased by purinergic signaling in adult mouse SVZ. $A$, Scheme of long-term BrdU administration and infusion. $\boldsymbol{B}$, BrdU-labeled cells in the contralateral SVZ ( $\boldsymbol{a}-\boldsymbol{c}$ ) and Hoechst staining of the same sections ( $\boldsymbol{d}-\boldsymbol{f}$ ). Mice were orally administered (in drinking water) BrdU for $14 \mathrm{~d}$ and then given normal water for $7 \mathrm{~d}$. After this treatment, $\operatorname{ATP}(\boldsymbol{a}, \boldsymbol{d}), \operatorname{PBS}(\boldsymbol{b}, \boldsymbol{e})$, or suramin $(\boldsymbol{c}, \boldsymbol{f})$ was continuously infused into the LV for $7 \mathrm{~d}$. Scale bars, $100 \mu \mathrm{m}$. C, Quantitative analysis of $\mathrm{BrdU}^{+}$cells in the contralateral SVZ. Mice were orally administered (in drinking water) BrdU for $14 \mathrm{~d}$, and then given normal water for $7 \mathrm{~d}$. After this treatment, ATP, PBS, or suramin was continuously infused into the LV for $7 \mathrm{~d}$. Values represent the mean \pm SEM. ${ }^{*} p<0.05$ vs PBS-infused brain ( $n=6$ per group).

anti-GFAP (1:200; Sigma), goat polyclonal anti-doublecortin (1:200; Santa Cruz Biotechnology), mouse monoclonal anti-Mash1 (1:200; PharMingen), rat monoclonal anti-BrdU (1:200; Abcam), rabbit polyclonal anti-Ibal (1:200; Wako) and rabbit polyclonal anti-P2Y1 receptor (1:200; MBL International).

Quantitative analysis of immunohistochemistry. Using the vibratome sectioning system, a complete set of coronal sections of the forebrain was first prepared. For each protein, a set of two random-systematically selected coronal sections, one from the anterior half (between $1.18 \mathrm{~mm}$ anterior and $0.58 \mathrm{~mm}$ anterior to bregma) and the other from the posterior half (between $0.58 \mathrm{~mm}$ anterior and $0.02 \mathrm{~mm}$ posterior to bregma) of the anterior horn, was subjected to immunohistochemical analysis (Adachi et al., 2007). Imaging was performed using a PASCAL Laser Scanning Confocal Microscope or LSM700 Laser Scanning Confocal Microscope (both Zeiss). Quantitative analysis was performed with two randomly selected sections from at least two different mice. The total numbers of detectable cells for each marker were counted in the SVZ on the side contralateral to the infusion.

Statistical analysis. All quantified data are expressed as the mean \pm SEM. Differences between two mean values were evaluated with the unpaired Student's $t$ test and considered statistically significant when the $p$ value was $<0.05$.

\section{Results}

ATP promotes proliferation of rapidly dividing cells and Type C cells

ATP has been shown to promote not only the proliferation of radial glial cells in the fetal brain, but also the expansion of neurospheres derived from both adult SVZ and fetal cortex
(Weissman et al., 2004; Mishra et al., 2006; Lin et al., 2007). Therefore, it has been suggested that ATP can act as a trophic factor, which is defined as an extracellular substance that stimulates cell division and/or proliferation, in adult neurogenesis. However, whether ATP has in vivo trophic functions in the SVZ and, if so, which cell type(s) is/are affected by ATP has remained unclear.

Two major types of proliferating cells are found in the SVZ: rapidly dividing transit-amplifying cells (Type C cells) and slowly dividing neural stem cells (NSCs; Type B cells). We first investigated whether ATP has trophic effects on these two cell types. When applied, the thymidine analog BrdU becomes incorporated into the replicating DNA during the $\mathrm{S}$ phase of the cell cycle. Thus, mitotic cells can be identified with anti-BrdU antibodies. Short administration of BrdU mainly labels rapidly dividing cells, which include rapidly dividing Type $\mathrm{C}$ cells, whereas long BrdU administration together with $7 \mathrm{~d}$ washout time mainly labels slowly dividing cells which include slowly dividing Type B cells (Doetsch et al., 1999; Johansson et al., 1999; Sakaguchi et al., 2006; Imaizumi et al., 2011).

The LVs of 8-week-old mice were continually infused with ATP, an ATP antagonist or PBS for $3 \mathrm{~d}$. Mice were then injected with BrdU every $200 \mathrm{~min}$ for $10 \mathrm{~h}$ before they were killed ("short-term" BrdU labeling method; Fig. $1 A$ ). As a first step to examine the role of $\mathrm{P} 2 / \mathrm{ATP}$ receptor in neurogenesis, we also used a broad-spectrum $\mathrm{P} 2$ receptor antagonist, suramin. Doses of either $2 \mu \mathrm{g} \cdot \mathrm{kg}^{-1} \cdot \mathrm{h}^{-1}$ ATP or 24 $\mu \mathrm{g} \cdot \mathrm{kg}^{-1} \cdot \mathrm{h}^{-1}$ suramin were used for these experiments. PBS was infused into control mice. Brain sections of these mice including the SVZ were then immunostained with anti-BrdU antibody, and the number of $\mathrm{BrdU}^{+}$cells in the SVZ was determined. To exclude the possible inflammatory effects of infusion, the side of the $\mathrm{LV}$ contralateral to the infusion was examined. BrdU ${ }^{+}$cells were significantly increased in the ATP-infused group compared with the PBS-infused control group (Fig. $1 A-C ; p<0.05 ; n=6$ each). In contrast, the number of $\mathrm{BrdU}^{+}$cells significantly decreased in the suramin-infused group compared with the PBS-infused control (Fig. $1 B, C ; p<0.05 ; n=6$ per group). BrdU labels dividing cells and dead cells (Cooper-Kuhn and Kuhn, 2002). We therefore also performed immunohistochemistry to analyze the sections for activated Caspase 3. While we detected $>170 \mathrm{BrdU}$ positive cells, we only found less than one activated Caspase 3 -positive cell per section in ATP-, suramin-, and PBS-infused mice (ATP-infusion group $0.75 \pm 0.89$, PBS-infused group $0.25 \pm 0.46$, suramin-infused group $0.75 \pm 0.89 ; n=4$ per group). Collectively, very little ongoing cell death was detected in the adult SVZ and BrdU- /activated Caspase 3-double-positive cells were very rare, suggesting that actually proliferating cells, but not dead or dying cells, incorporated BrdU.

To identify the cell type(s) that displayed increased proliferation upon ATP infusion, sections of ATP-treated mice were pro- 

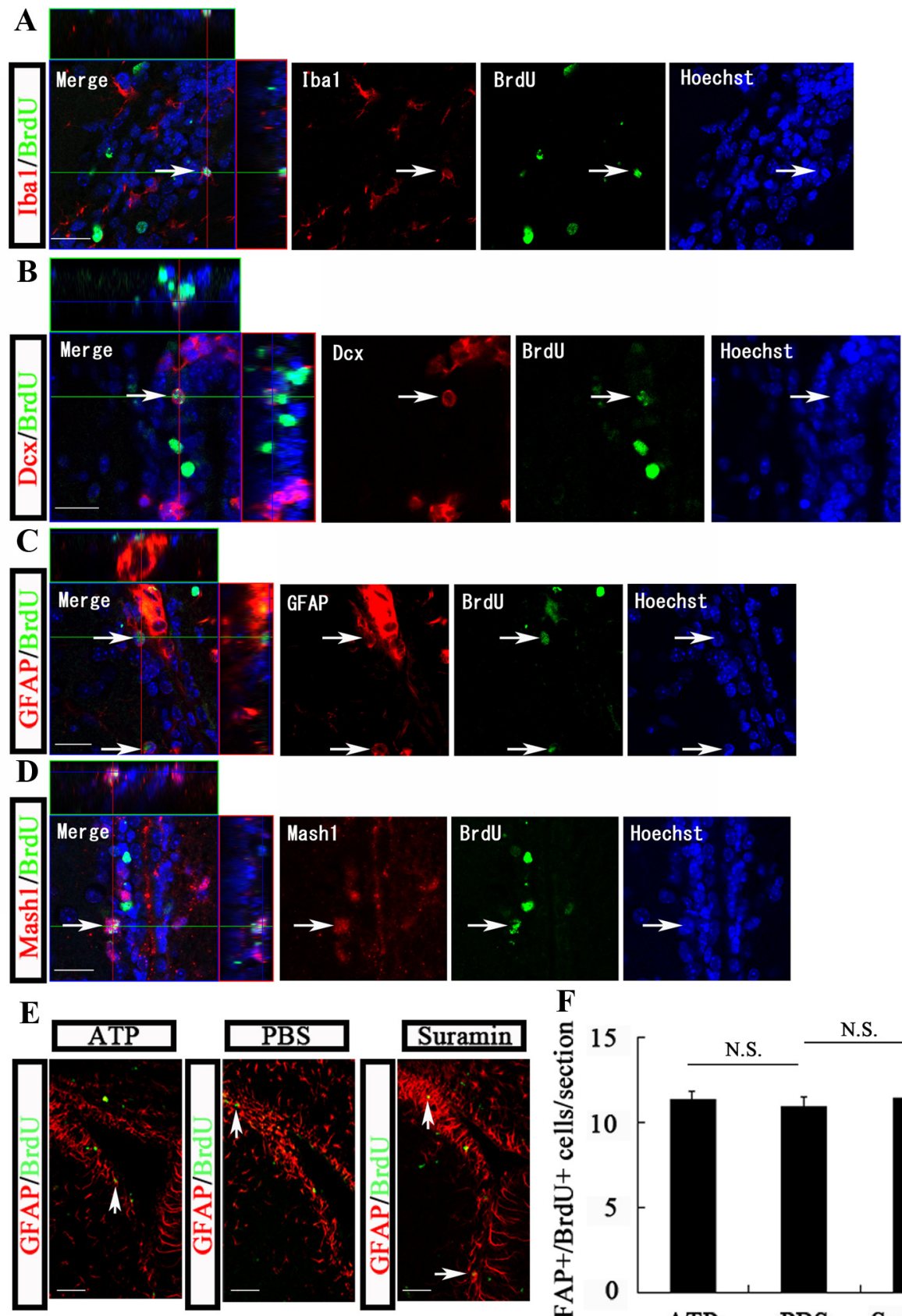

F

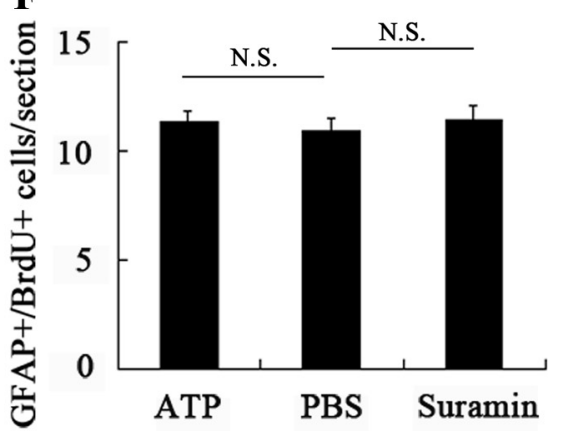

Figure 4. ATP does not promote proliferation of Type B cells in adult mouse SVZ. $\boldsymbol{A}-\boldsymbol{D}$, Immunohistochemical analysis of BrdU ${ }^{+}$cells in ATP-infused mice with Iba1 $(\boldsymbol{A})$, Dcx $(\boldsymbol{B})$, GFAP $(\boldsymbol{C})$, and Mash1 (D). Mice were orally administered (in drinking water) BrdU for $14 \mathrm{~d}$ and then given normal water for $7 \mathrm{~d}$. After this treatment, ATP was continuously infused into the LV for $7 \mathrm{~d}$. Immunohistochemical analysis of BrdU ${ }^{+}$cells were performed with the contralateral SVZ. Colocalization of each cell marker with BrdU was assessed by counting 579 BrdU-positive cells in Iba1 ( $A$ ), 523 cells in Dcx (B), 220 cells in GFAP ( $\boldsymbol{C}$ and 270 cells in Mash1 (D). Scale bars, $40 \mu \mathrm{m}$ ( $n=3$ per group). $\boldsymbol{E}$, BrdU/GFAP double-positive cells in the contralateral SVZ. Mice were orally administered (in drinking water) BrdU for $14 \mathrm{~d}$ and then given normal water for $7 \mathrm{~d}$. After this treatment, ATP, PBS, or suramin was continuously infused into the LV for $7 \mathrm{~d}$. Scale bars, $100 \mu \mathrm{m}$. F, Quantitative analysis of BrdU/GFAP double-positive cells in the contralateral SVZ. Mice were orally administered (in drinking water) BrdU for $14 \mathrm{~d}$ and then given normal water for $7 \mathrm{~d}$. After this treatment, ATP, $\mathrm{PBS}$, or suramin was continuously infused into the LV for $7 \mathrm{~d}$. Values represent the mean \pm SEM. ${ }^{*} p<0.05$ vs PBS-infused brain ( $n=6$ per group).

cessed for double-label immunohistochemistry with an antibody against $\mathrm{BrdU}$ in combination with one of the following cell typespecific markers: microglial cell marker Ibal (Imai et al., 1996), Type A cell marker doublecortin (Dcx; Doetsch et al., 1997), Type B cell marker GFAP (Doetsch et al., 1997, 1999), and Type C cell marker Mash1 (Parras et al., 2004; Sakaguchi et al., 2006; Adachi et al., 2007; Kim et al., 2007, 2011). Microglial cells become activated by purinergic signaling upon inflammation (Färber and Kettenmann, 2006; Inoue, 2008). We found that $49.6 \%$ of BrdU-positive cells also expressed one of these cell type-specific markers. Among these double-positive cells, the largest fraction (38.3\%) comprised Mash1positive cells, whereas $36.8 \%$ were Dcx-positive Type A cells and $6.8 \%$ were GFAP-positive Type B or glial cells. Also, $18.2 \%$ of BrdUpositive cells were Iba1-positive microglial cells (Fig. $2 A-D$ ). These data indicate that the fraction of Type $\mathrm{C}$ cells within the total $\mathrm{BrdU}^{+}$ cell population was increased significantly by ATP infusion. Therefore, we next examined whether the number of Mash1-positive cells was increased by ATP infusion. 

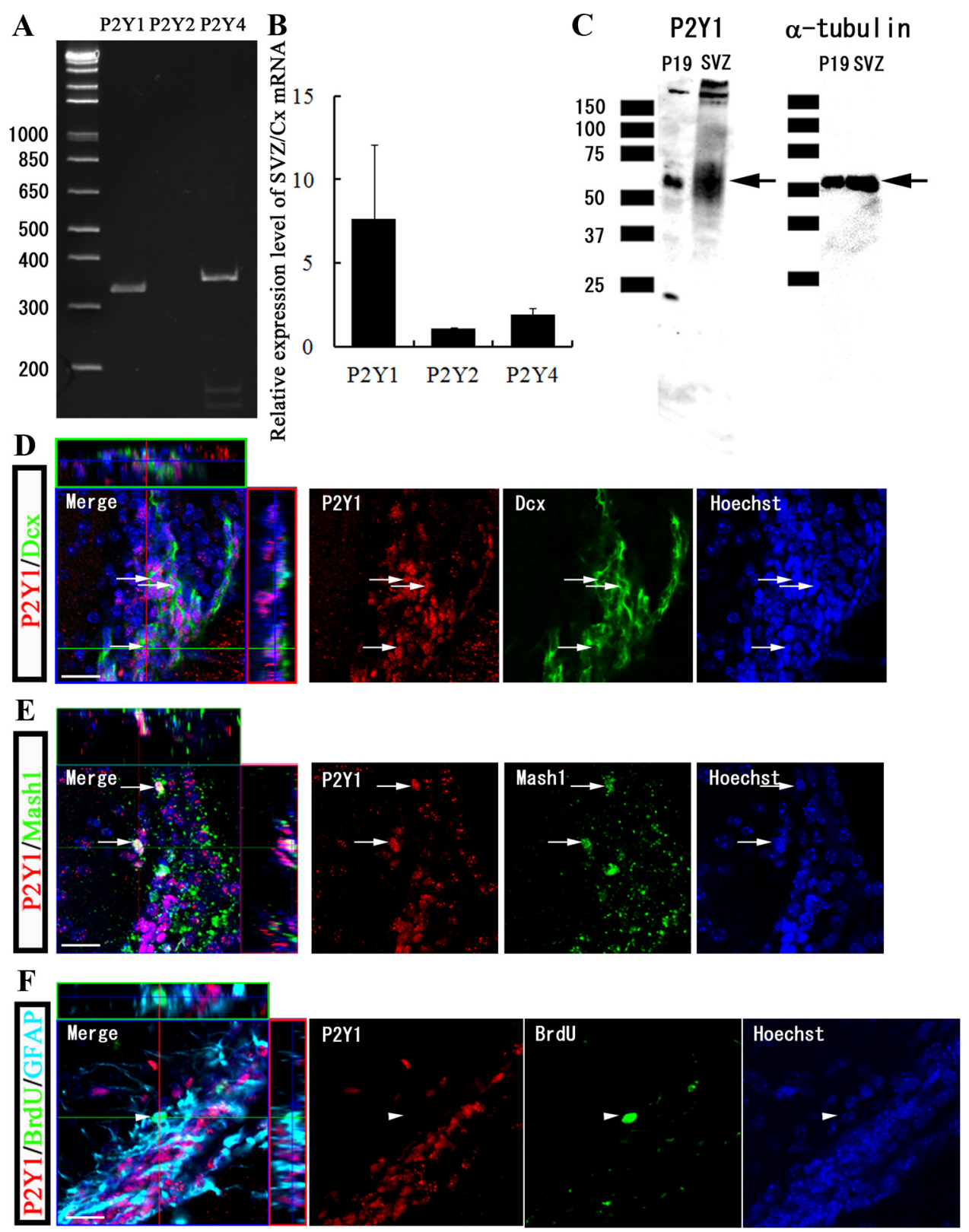

Figure 5. $P 2 Y 1$ receptor expression in the adult mouse SVZ. A, mRNA expression of P2Y1, $P 2 Y 2$ or P2Y 4 receptor in the SVZ. RT-PCR analysis of adult mouse SVZ is shown. $\boldsymbol{B}$, The relative expression level of mRNAs of P2 receptors (P2Y1, P2Y2 and P2Y4) in SVZ versus cortex (SVZ/CX). Real-time PCR analysis was performed using SVZ and cortex RNA samples. Values represent the mean \pm SEM $(n=3)$. C, Protein expression of the P2Y1 receptor in SVZ. Immunoblots of adult mouse SVZ and P19 lysates are shown. $\boldsymbol{D}-\boldsymbol{F}$, Immunohistochemical analysis of P2Y1-positive cells in the adult mouse SVZ. Dcx-positive Type A cells $(\boldsymbol{D})$ and Mash1-positive Type C cells $(\boldsymbol{E})$ are P2Y1 positive, but GFAP-positive Type B cells $(\boldsymbol{F})$ are P2Y1 negative. Colocalization of each cell marker with P2Y1 was assessed by counting 751 Dcx-positive cells $(\boldsymbol{D}), 381$ Mash1-positive cells $(\boldsymbol{E})$, and 11 BrdU/GFAP double-positive cells $(\boldsymbol{F})$. Scale bars, $20 \mu \mathrm{m}$ ( $n=3$ per group).

Quantification of Mash1 ${ }^{+}$cells in ATP-, suramin-, and PBSinfused mice revealed a significant increase in Mash1 ${ }^{+}$cells in the ATP-infused group ( $p<0.05 ; n=6$ per group), and a nonsignificant decrease in the suramin-infused group $(p=0.07)$, relative to the PBS-infused control group (Fig. $2 E, F$ ).

\section{ATP does not affect the proliferation of slowly dividing cells and Type B cells}

Next, we examined whether ATP has similar trophic functions in slowly dividing cells. Since Type B cells divide slowly, a "long-term" BrdU labeling protocol was used for labeling of slowly dividing cells and Type B cells. To this end, mice were orally administered (in drinking water) BrdU for $14 \mathrm{~d}$. Following the BrdU administration, normal water was then provided for $7 \mathrm{~d}$ as (Fig. $3 A$ ). After this treat- ment, $2 \mu \mathrm{g} \cdot \mathrm{kg}^{-1} \cdot \mathrm{h}^{-1}$ ATP, $24 \mu \mathrm{g} \cdot \mathrm{kg}^{-1} \cdot \mathrm{h}^{-1}$ suramin, or PBS was continuously infused into the LV for $7 \mathrm{~d}$. The effects of purinergic signaling on Type B cells were then analyzed. As above, the number of $\mathrm{BrdU}^{+}$cells in the SVZ on the side contralateral to the infusion was counted. The number of $\mathrm{BrdU}^{+}$cells did not change in the ATP-infused or suramin-infused group compared with the PBSinfused control group (Fig. $3 B, C ; n=6$ per group).

To characterize the BrdU-positive cells, we performed immunohistochemistry to analyze brain sections in the same manner as above. We found that $50.1 \%$ of BrdU-positive cells expressed one of these markers. In these double-positive cells, the largest fraction was GFAP positive; $38.1 \%$ were GFAPpositive Type B or glial cells, 22.1\% were Dcx-positive Type A cells, $17.7 \%$ were Mash1-positive Type C cells and $22.1 \%$ of 


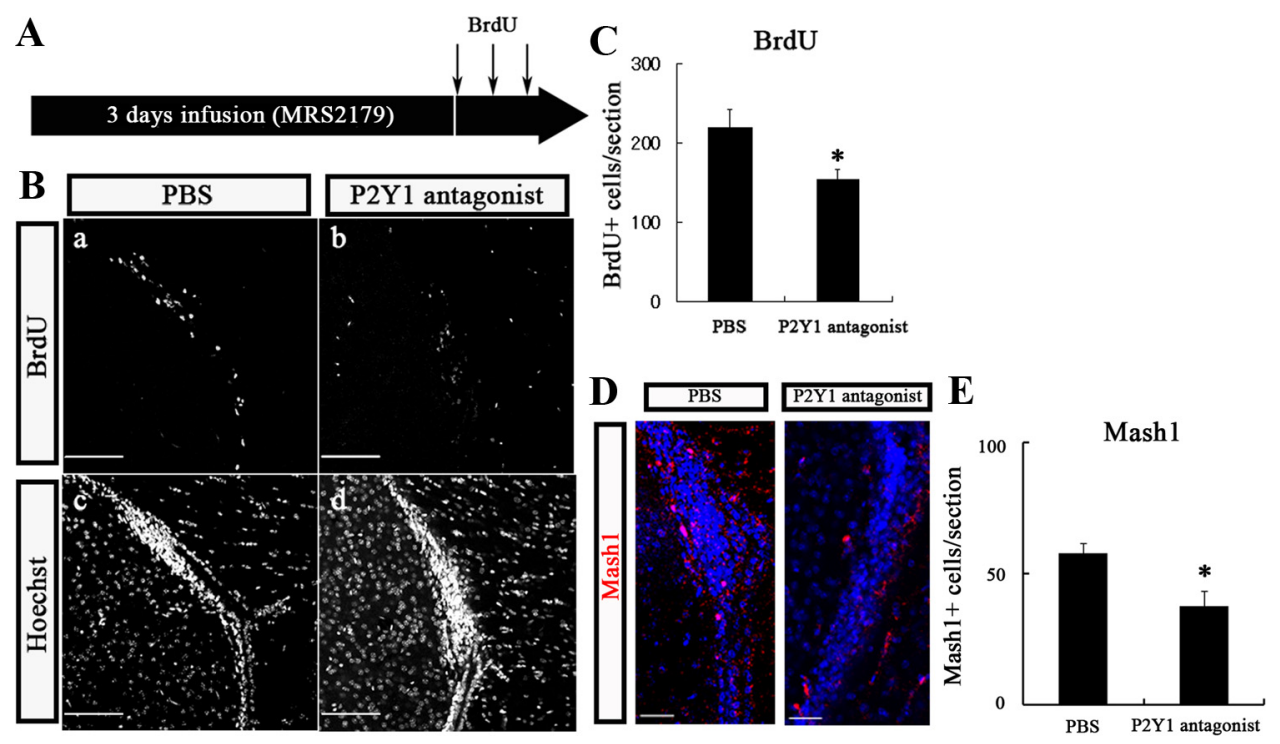

Figure 6. ATP-mediated proliferation of rapidly dividing cells and Type C cells was mainly mediated by the P2Y1 receptor in the adult mouse SVZ. A, Scheme of infusion and short-term BrdU administration. $\boldsymbol{B}$, BrdU-labeled cells in the contralateral SVZ $(\boldsymbol{a}, \boldsymbol{b})$ and Hoechst staining of the same sections $(\boldsymbol{c}, \boldsymbol{d})$. Mice were treated with continual infusion of MRS2179 $(\boldsymbol{b}, \boldsymbol{d})$ or PBS $(\boldsymbol{a}, \boldsymbol{c})$ into the LV for $3 \mathrm{~d}$, followed by three intraperitoneal injections of BrdU every $200 \mathrm{~min}$ for $10 \mathrm{~h}$ before they were killed. Scale bars, $100 \mu \mathrm{m}$. C, Quantitative analysis of BrdU ${ }^{+}$cells in the contralateral SVZ. Mice were continually infused with MRS2179 into the LV for $3 \mathrm{~d}$, and then injected with BrdU every $200 \mathrm{~min}$ for $10 \mathrm{~h}$ before they were killed. Values represent the mean \pm SEM. ${ }^{*} p<0.05$ vs PBS-infused brain ( $n=6$ per group). D, Mash1-labeled cells in the contralateral SVZ. Mice were continually infused with PBS or MRS2179 into the LV for $3 \mathrm{~d}$, and then injected with BrdU every 200 $\min$ for $10 \mathrm{~h}$ before they were killed. Scale bars, $100 \mu \mathrm{m}$. E, Quantitative analysis of Mash $1^{+}$cells in the contralateral SVZ. Mice were continually infused with PBS or MRS2179 into the LV for $3 \mathrm{~d}$, and then injected with BrdU every $200 \mathrm{~min}$ for $10 \mathrm{~h}$ before they were killed. Values represent the mean \pm SEM. ${ }^{*} p<0.05$ vs PBS-infused brain $(n=6$ per group).

BrdU-positive cells were Iba1-positive microglial cells (Fig. $4 A-D)$.

Then, we examined whether or not GFAP-positive cells were increased by ATP infusion. We, therefore, counted the number of BrdU/GFAP double-positive Type B and glial cells in ATPinfused mice by using histochemical analysis. The number of double-positive cells in the ATP-infused or suramin-infused groups did not significantly differ from the number of these cells in the PBS-infused control group (Fig. $4 E, F ; n=6$ per group).

$\mathrm{P} 2 \mathrm{Y} 1$ receptor is a mediator of $\mathrm{ATP}$-induced proliferation of rapidly dividing cells and Type $C$ cells

To gain insight into the involvement of purinergic signaling receptors in the ATP-mediated promotion of Type C cell proliferation, we next assessed their expression patterns in the adult mouse SVZ by semiquantitative PCR, immunoblot analysis, and immunohistochemistry.

As mentioned above, P2Y1, P2Y2 and P2Y4 receptor expression has been suggested in the SVZ (Mishra et al., 2006; Lin et al., 2007), and P2Y1 and P2Y2 receptors were shown to be involved in the proliferation of adult SVZ-derived neurospheres (Mishra et al., 2006). To determine which type(s) of P2Y receptors were crucial for ATP-mediated promotion of rapidly dividing cell proliferation, reverse transcriptase (RT)-PCR analysis was performed using RNA prepared from adult mouse SVZ. The results of the semiquantitative RT-PCR analysis showed that P2Y1 and $\mathrm{P} 2 \mathrm{Y} 4$ receptors were more highly expressed in the adult mouse SVZ than P2Y2 receptors (Fig. 5A). Additional cycles of amplification were needed to detect $\mathrm{P} 2 \mathrm{Y} 2$ receptors.

To address the importance of these receptors in the adult SVZ, we compared the expression patterns of these receptors between the SVZ and cortex using real-time PCR. The results revealed that the relative expression levels in the SVZ compared with the cortex were higher for P2Y1 $(\sim 7)$ than P2Y4 $(\sim 4)$ (Fig. $5 B)$. This indicates the importance of $\mathrm{P} 2 \mathrm{Y} 1$ for adult neurogenesis in the neu- rogenic niche. Moreover, previous data suggested that the P2Y1 receptor is the main receptor necessary for ATP-mediated radial glia proliferation and expansion of neurospheres derived from the fetal brain or adult SVZ. These data suggest that P2Y1 is the major purinergic receptor responsible for the ATP-induced promotion of rapidly dividing cell proliferation in the SVZ. Therefore we focused on the P2Y1 receptor.

Immunoblot analysis was performed using lysates prepared from the adult mouse SVZ to investigate whether $\mathrm{P} 2 \mathrm{Y} 1$ protein is expressed in the SVZ. The mouse embryonal carcinoma cell line $\mathrm{P} 19$, which is known to express the P2Y1 receptor (Resende et al., 2007), was used as a positive control. Interestingly, P2Y1 expression was observed in the SVZ (Fig. 5C). To determine which cell type expressed the P2Y1 receptor in the SVZ, we performed immunohistochemistry using antibodies against Dcx, Mash1, and GFAP. The P2Y1 receptor was expressed in $73.2 \%$ of Dcx ${ }^{+}$Type A and $31.1 \%$ of Mash $1^{+}$Type C cells, but not in BrdU/GFAP double-positive Type B cells (Fig. 5D-F).

To confirm that the $\mathrm{P} 2 \mathrm{Y} 1$ receptor is indeed involved in the ATPmediated promotion of rapidly dividing cell proliferation, $6 \mu \mathrm{g} \cdot$ $\mathrm{kg}^{-1} \cdot \mathrm{h}^{-1}$ of the novel P2Y1-specific antagonist MRS2179 was continuously infused into the LVs of 8-week-old mice for $3 \mathrm{~d}$, followed by short-term BrdU labeling (Fig. 6A). The infused brains were then subjected to immunohistochemical analysis. The number of $\mathrm{BrdU}^{+}$ cells was significantly lower in the MRS2179-infused group than in the PBS-infused control group (Fig. $6 B, C ; p<0.05 ; n=6$ per group). The number of Mash1-positive cells was also significantly lower in the MRS2179-infused group than in the PBS-infused control group (Fig. $6 D, E ; p<0.05 ; n=6$ per group). We also performed immunohistochemistry to analyze the sections for activated Caspase 3 to determine whether MRS2179 infusion affected cell death. The amount of activated Caspase 3 was not significantly different between the MRS2179-infused group and the PBS-infused group (PBS-infused group, $0.25 \pm 0.46$; MRS2179-infused group, $0.25 \pm 0.27 ; n=4$ per group). 

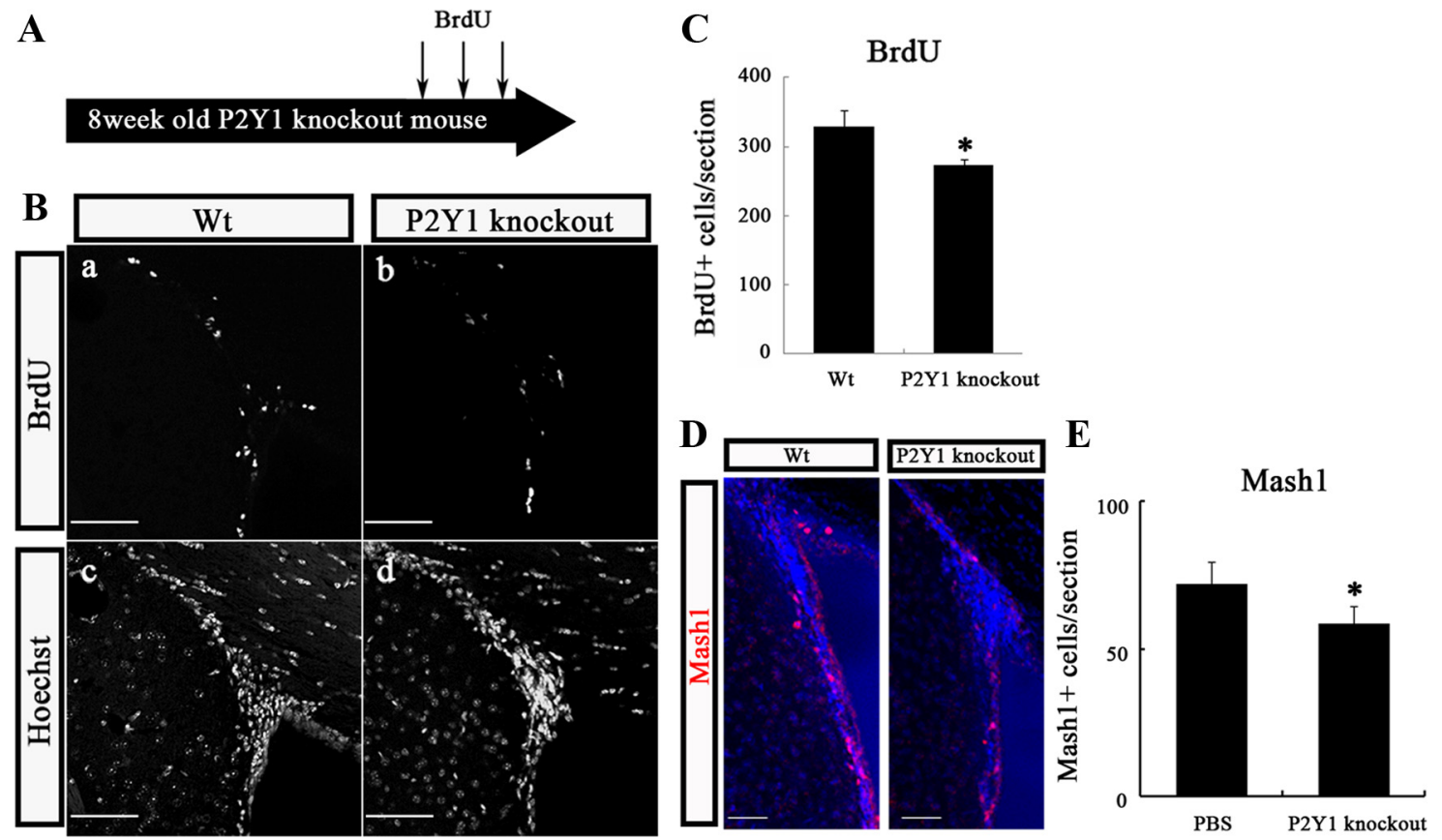

Figure 7. P2Y1 knock-out mice show decreased proliferation of rapidly dividing cells and Type ( cells. $\boldsymbol{A}$, Scheme of short-term BrdU administration. $\boldsymbol{B}, \operatorname{BrdU}$-labeled cells in the SVZ ( $\boldsymbol{a}, \boldsymbol{b})$ and Hoechst staining of the same sections $(\boldsymbol{c}, \boldsymbol{d})$ from a P2Y1 knock-out mouse $(\boldsymbol{b}, \boldsymbol{d})$ and wild-type mouse $(\boldsymbol{a}, \boldsymbol{c})$. Mice were treated by three intraperitoneal injections of BrdU every $200 \mathrm{~min}$ for $10 \mathrm{~h}$ before they were killed. Scale bars, $100 \mu \mathrm{m}$. C, Quantitative analysis of BrdU ${ }^{+}$cells in the SVZ of P2Y1 knock-out mice. Values represent the mean \pm SEM. ${ }^{*} p<0.05 \mathrm{vs}$ wild-type mouse brain $(n=6$ per group). D, Mash1-labeled cells in the wild-type or P2Y1 knock-out mouse SVZ. Scale bars, $100 \mu \mathrm{m}$. E, Quantitative analysis of Mash1 ${ }^{+}$cells in the wild-type or P2Y1 knock-out mouse SVZ. Values represent the mean \pm SEM. ${ }^{*} p<0.05$ vs wild-type mouse brain ( $n=7$ per group).
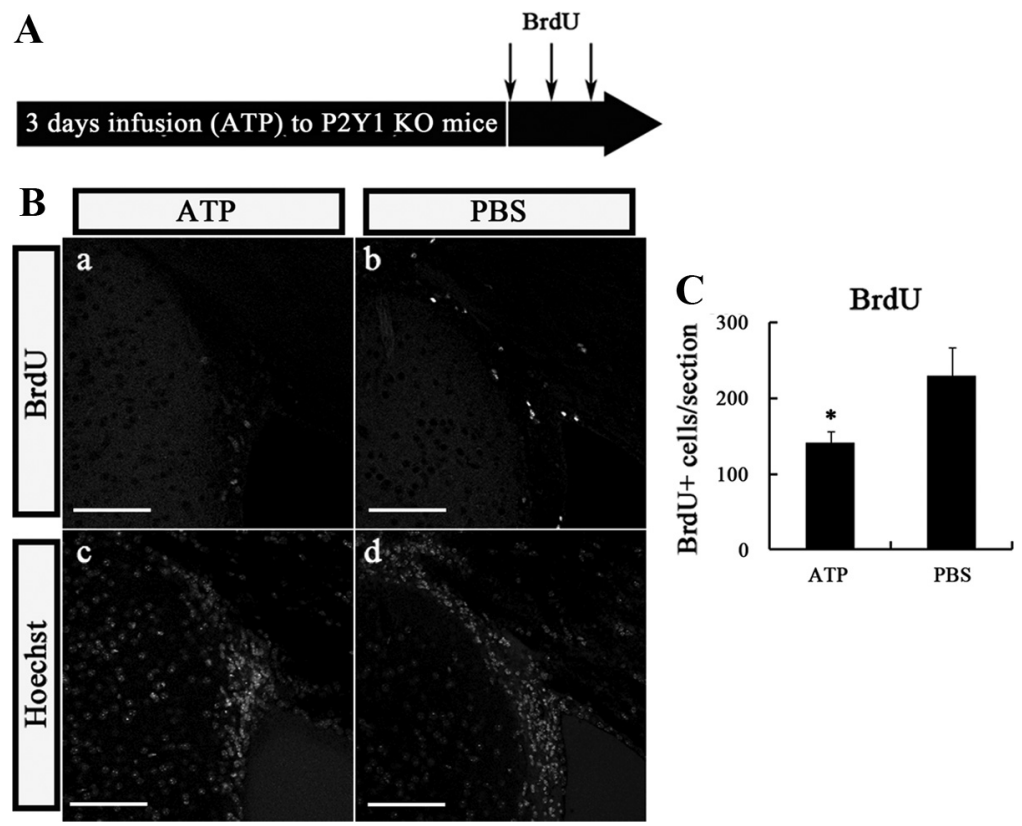

Figure 8. ATP-mediated proliferation of rapidly dividing cells was not detected in P2Y1 knock-out mice. A, Scheme demonstrating protocols for infusion and short-term BrdU administration. $\boldsymbol{B}$, BrdU-labeled cells in the contralateral SVZ $(\boldsymbol{a}, \boldsymbol{b})$ and Hoechst staining of the same sections $(\boldsymbol{c}, \boldsymbol{d})$. Mice were continually infused with $\operatorname{ATP}(\boldsymbol{a}, \boldsymbol{c})$ or PBS $(\boldsymbol{b}, \boldsymbol{d})$ into the LV for $3 \mathrm{~d}$, and then injected with BrdU every $200 \mathrm{~min}$ for $10 \mathrm{~h}$ before they were killed. Scale bars, $100 \mu \mathrm{m}$. C, Quantitative analysis of BrdU ${ }^{+}$cells in the contralateral SVZ. Mice were continually infused with ATP into the LV for $3 \mathrm{~d}$, and then injected with BrdU every $200 \mathrm{~min}$ for $10 \mathrm{~h}$ before they were killed. Values represent the mean \pm SEM. ${ }^{*} p<0.05$ vs PBS-infused brain ( $n=6$ per group).

To further investigate the functions of the P2Y1 receptor, we analyzed the proliferation of rapidly dividing cells in P2Y1 knockout mice. It is important to note that, whereas the other experiments investigated the effects of purinergic signaling in CD-1mice, the
P2Y1 knock-out mice were on a C57BL/6 background. Since adult neurogenesis is differentially influenced by the genetic background of the mice (Kempermann et al., 1997; Schauwecker, 2006), we examined whether the different genetic backgrounds had an impact on our study. We performed the experiments using the P2Y1-specific antagonist and C57BL/6 mice, and confirmed that the number of BrdU-positive cells was significantly reduced in the MRS2179 infusion group $\left(240 \pm 17\right.$ cells, ${ }^{\star} p<0.05$ vs PBS-infused brain, $n=6$ ) compared with the PBS-infused control group (322 \pm 37 cells, $n=6$ ). This was the same result that we observed using CD-1 mice. Therefore, we used P2Y1-deficient mice on a C57BL/6 background to further investigate $\mathrm{P} 2 \mathrm{Y} 1$ receptor functions. Adult neurogenesis was examined in P2Y1-deficient mice with short-term BrdU labeling (Fig. 7A). The number of BrdU- and Mash1-positive cells were both significantly lower in P2Y1deficient mice than in wild-type mice (Fig. $7 B-E ; p<0.05 ; n=6$ per group). The number of activated Caspase3-positive cells was similar in P2Y1-deficient mice and wildtype mice (WT, $1.5 \pm 0.38$; P2Y1-deficient, $1.13 \pm 1.48 ; n=4$ per group). To determine whether P2Y1 is required for ATP mitogenic stimulation, ATP was continuously infused into the LVs of 8-week-old wild and P2Y1-deficient mice for $3 \mathrm{~d}$. We then performed short-term BrdU labeling (Fig. 8A) and subjected the in- 
fused brains to immunohistochemical analysis. The ATP-infusion did not increase the number of $\mathrm{BrdU}^{+}$cells in P2Y1-deficient mice (Fig. $8 B, C ; n=6$ per group), suggesting that $\mathrm{P} 2 \mathrm{Y} 1$ was required for ATP mitogenic stimulation. On the other hand, the number of $\mathrm{BrdU}^{+}$cells was significantly lower in the SVZ of P2Y1-deficient mice brains than in the PBS-infused control group (Fig. $8 B, C ; n=6$ per group). However, the mechanism responsible for this decrease still remains unknown.

Together, these results strongly suggest that ATP-induced promotion of the proliferation of rapidly dividing cells and Type $\mathrm{C}$ cells is mainly mediated by the $\mathrm{P} 2 \mathrm{Y} 1$ receptor.

\section{Discussion}

Persistent neurogenesis has been shown to occur in two restricted areas of the adult mammalian brain: the SVZ (Alvarez-Buylla and Garcia-Verdugo, 2002) and the SGZ of the hippocampus (Okano, 2002; Kempermann et al., 2004; Okano et al., 2008). Although the molecular mechanisms of adult neurogenesis have been extensively investigated, the in vivo roles of purinergic signaling in adult neurogenesis have not yet been elucidated.

Purinergic signaling, mainly mediated by ATP, has been speculated to regulate adult neurogenesis because it is important for the proliferation of various cell types during development (Zimmerman, 2006), including cortical radial glial cells (Weissman et al., 2004), retinal progenitors (Sugioka et al., 1996; Pearson et al., 2002; Nunes et al., 2007), and olfactory epithelium progenitors (Hassenklöver et al., 2009) in the CNS. Purinergic signaling receptors and nucleotide breakdown enzymes such as ectonucleoside triphosphate diphosphohydrolase 2 (NTPDase2) and tissue-nonspecific alkaline phosphatase are also present in the SVZ (Braun et al., 2003; Langer et al., 2007). Moreover, adenosine kinase, which controls adenosine homeostasis and ATP synthesis, is highly expressed in the SVZ. The existence of these enzymes in the SVZ strongly indicates the importance of purinergic signaling in the region. In addition, although ATP is not suitable for distal extracellular signaling because it is unstable and subject to rapid degradation, it is suitable for cell-cell communication within microenvironments such as the SVZ niche (Yegutkin, 2008).

These previous reports support the hypothesis that ATP plays important roles in adult neurogenesis in the SVZ. In this study, we attempted to elucidate whether ATP-mediated purinergic signaling functions to promote the proliferation of cells in the SVZ. Infusion of ATP into the LVs of adult mice increased the number of BrdUpositive and Mash1-positive cells, whereas suramin infusion decreased these numbers. As mentioned above, BrdU labels both dying and newborn cells (Cooper-Kuhn and Kuhn, 2002). The increase in BrdU-positive cells, therefore, could reflect increased apoptosis. However, immunohistochemical analysis revealed that $<0.4 \%$ of BrdU-positive cells were also positive for activated Caspase3. Thus, BrdU immunoreactivity was rarely identified in apoptotic cells, and minimal cell death was observed in the SVZ. These results suggest that the majority of the BrdU-positive cells were newborn, rather than dying, cells. Furthermore, our data showed no significant difference in the number of apoptotic cells when either purinergic signaling antagonist-infused or P2Y1-deficient mice were compared with WT mice. Thus, it is unlikely that purinergic signaling plays a major role in regulating cell death/survival in the adult SVZ. It is also true that BrdU-positive cells merely represent that the cells have been entered or had been entered S phase. However, the increased number of Mash1-positive cells was observed in ATP-infused mice as well as the number of BrdU-positive cells. These data suggested that most BrdU-positive cells had been survived. Therefore, our results suggest that purinergic signaling promotes the proliferation of rapidly dividing cells.

We next investigated the involvement of purinergic signaling receptors in the ATP-mediated promotion of cell proliferation. Expression of the purinergic signaling receptors $\mathrm{P} 2 \mathrm{Y} 1, \mathrm{P} 2 \mathrm{Y} 2$, and $\mathrm{P} 2 \mathrm{Y} 4$ and their contribution to the proliferation of neuronal precursor cells in the SVZ have been previously suggested (Mishra et al., 2006; Lin et al., 2007). However, the cell types in the SVZ that express these receptors have not been elucidated. Our data revealed that the P2Y1 receptor is expressed in $73.2 \%$ of Type A and $31.1 \%$ of Type C cells.

To investigate the role of the $\mathrm{P} 2 \mathrm{Y} 1$ receptor, in the ATPmediated promotion of the proliferation of rapidly dividing cells, the P2Y1 receptor-specific antagonist MRS2179 was infused into the LVs of adult mice, and a decrease was observed in the number of $\mathrm{BrdU}^{+}$cells (after a short-term labeling protocol). The number of Mash1-positive cells was also decreased in the MRS2179infused mice. Then, we further analyzed it in P2Y1 deficient mice.

P2Y1 knock-out mice are viable, with no apparent abnormalities affecting their development, survival, or reproduction (Léon et al., 1999). Additionally, thorough examinations have revealed abnormal platelet aggregation and impaired long-term depression in the prefrontal cortex in those animals (Léon et al., 1999; Guzman et al., 2010). These reports indicate the possibility of the presence of other abnormalities in the P2Y1 knock-out mice. In this study, we revealed that rapidly dividing cells and Type C cells were decreased in P2Y1 knock-out mice. Moreover, proliferation of rapidly dividing cells was reduced in ATP-infused P2Y1 knock-out mice compared with the PBS-infused ctrl P2Y1 knock-out mice group. These data also indicate the importance of purinergic signaling via $\mathrm{P} 2 \mathrm{Y} 1$ receptors. Further studies using P2Y1 knock-out mice are necessary to determine the signal cascade downstream of P2Y1.

What is the source of ATP? The SVZ contains many candidate ATP sources including blood vessels, proliferating cells, neurons, astroglial cells, and microglial cells (Weissman et al., 2004; Fields and Burnstock, 2006). Previous reports demonstrate that many cell types release ATP, including proliferating cells, neurons, and astrocytes (Burnstock, 2007). Also, in the fetal cortex, radial glial cells have been reported to secrete ATP through connexin hemichannels during S phase (Weissman et al., 2004). Furthermore, endothelial cells in the adult mouse SVZ express connexin (Cx), and it is known that neocortical astrocytes release ATP via Cx43 (Haas et al., 2006). Thus, many cell types might release ATP depending on the cues or demands of the SVZ niche.

This study demonstrated that ATP is an important small molecule for the proliferation of rapidly dividing cells and Type C cells in the adult mouse SVZ. Thus, purinergic signaling in the SVZ niche is important for the maintenance of adult neurogenesis in this niche. The physiological functions of purinergic signaling in the SVZ, however, still remain largely unknown. Better understanding of the diverse functions and complicated mechanisms of purinergic signaling in the SVZ will provide more detailed insights into the molecular mechanisms of adult neurogenesis and the homeostasis of the nervous system.

\section{References}

Adachi K, Mirzadeh Z, Sakaguchi M, Yamashita T, Nikolcheva T, Gotoh Y, Peltz G, Gong L, Kawase T, Alvarez-Buylla A, Okano H, Sawamoto K (2007) $\beta$-Catenin signaling promotes proliferation of progenitor cells in the adult mouse subventricular zone. Stem Cells 25:2827-2836.

Alvarez-Buylla A, Garcia-Verdugo JM (2002) Neurogenesis in adult subventricular zone. J Neurosci 22:629-634.

Braun N, Sévigny J, Mishra SK, Robson SC, Barth SW, Gerstberger R, Hammer K, Zimmermann H (2003) Expression of the ecto-ATPase NTP- 
Dase2 in the germinal zone of the developing and adult rat brain. Eur J Neurosci 17:1355-1364.

Burnstock G (1996) Purinoceptors: ontogeny and phylogeny. Drug Dev Res 39:204-242.

Burnstock G (2007) Physiology and pathophysiology of purinergic neurotransmission. Physiol Rev 87:649-797.

Cooper-Kuhn CM, Kuhn HG (2002) Is it all DNA repair? Methodological consideration for detecting neurogenesis in the adult brain. Brain Res Dev Brain Res 124:13-21.

Doetsch F, García-Verdugo JM, Alvarez-Buylla A (1997) Cellular composition and three-dimensional organization of the subventricular germinal zone in the adult mammalian brain. J Neurosci 17:5046-5061.

Doetsch F, Caillé I, Lim DA, García-Verdugo JM, Alvarez-Buylla A (1999) Subventricular zone astrocytes are neural stem cells in the adult mammalian brain. Cell 97:703-716.

Färber K, Kettenmann H (2006) Purinergic signaling and microglia. Pflugers Arch 452:615-621.

Fields RD, Burnstock G (2006) Purinergic signaling in neuron-glia interactions. Nat Rev Neurosci 7:423-436.

Franke H, Krügel U, Illes P (2006) P2 receptors and neuronal injury. Pflugers Arch 452:622-644.

Fuchs E, Tumbar T, Guasch G (2004) Socializing with the neighbors: stem cells and their niche. Cell 116:769-778.

Guzman SJ, Schmidt H, Franke H, Krügel U, Eilers J, Illes P, Gerevich Z (2010) P2Y1 receptors inhibit long-term depression in the prefrontal cortex. Neuropharmacology 59:406-415.

Haas B, Schipke CG, Peters O, Söhl G, Willecke K, Kettenmann H (2006) Activity-dependent ATP-waves in the mouse neocortex are independent from astrocytic calcium waves. Cereb Cortex 16:237-246.

Hassenklöver T, Schwartz P, Schild D, Manzini I (2009) Purinergic signaling regulates cell proliferation of olfactory epithelium progenitors. Stem Cells 27:2022-2031.

Imai Y, Ibata I, Ito D, Ohsawa K, Kohsaka S (1996) A novel gene ibal in the major histocompatibility complex class3 region encoding and EF hand protein expressed in a monocytic lineage. Biochem Biophys Res Commun 224:855-862.

Imaizumi Y, Sakaguchi M, Morishita T, Ito M, Poirier F, Sawamoto K, Okano H (2011) Galectin-1 is expressed in early-type neural progenitor cells and down-regulates neurogenesis in the adult hippocampus. Mol Brain 4:7.

Inoue K (2008) Purinergic system in microglia. Cell Mol Life Sci 65:30743080.

Johansson CB, Momma S, Clarke DL, Risling M, Lendahl U, Frisén J (1999) Identification of Neural Stem Cell in the Adult Mammalian Central Nervous System. Cell 96:25-34.

Kempermann G, Kuhn HG, Gage FH (1997) Genetic influence on neurogenesis in the dentate gyrus of adult mice. Proc Natl Acad U S A 94:1040910414.

Kempermann G, Wiskott L, Gage FH (2004) Functional significance of adult neurogenesis. Curr Opin Neurobiol 14:186-191.

Kim EJ, Leung CT, Reed RR, Johnson JE (2007) In vivo analysis of Ascl1 defined progenitors reveals distinct development dynamics during adult neurogenesis and gliogenesis. J Neurosci 27:12764-12774.

Kim EJ, Ables JL, Dickel LK, Eisch AJ, Johnson JE (2011) Ascl1 (Mash1) defines cells with long-term neurogenic potential in subgranular and subventricular zones in adult mouse brain. PLoS One 6:e18472.

Langer D, Ikehara Y, Takebayashi H, Hawkes R, Zimmermann H (2007) The ectonucleotidases alkaline phosphatase and nucleoside triphosphate diphosphohydrolase 2 are associated with subsets of progenitor cell populations in the mouse embryonic, postnatal and adult neurogenic zones. Neuroscience 150:863-879.

Léon C, Hechler B, Freund M, Eckly A, Vial C, Ohlmann P, Dierich A, LeMeur M, Cazenave JP, Gachet C (1999) Defective platelet aggregation and increased resistance to thrombosis in purinergic $\mathrm{P} 2 \mathrm{Y} 1$ receptor-null mice. J Clin Invest 104:1731-1737.

Lin JHC, Takano T, Arcuino G, Wang X, Hu F, Darzynkiewicz Z, Nunes M,
Goldman SA, Nedergaard M (2007) Purinergic signaling regulates neural progenitor cell expansion and neurogenesis. Dev Biol 302:356-366.

Maria P, Burnstock G, Verkhratsky A, Zimmermann H (2008) Purinergic signaling in the nervous system: an overview. Trends Neurosci 10:001.

Mishra SK, Braun N, Shukla V, Fullgrabe M, Schomerus C, Korf HW, Gachet C, Ikehara Y, Sévigny J, Robson SC, Zimmermann H (2006) Extracellular nucleotide signaling in adult neural stem cells: synergism with growth factor mediated cellular proliferation. Development 133:675-684.

Nunes PH, Calaza KD, Albuquerque LM, Fragel-Madeira I, Sholl-Granco A, Ventura AL (2007) Signal transduction pathways associated with ATPinduced proliferation of cell progenitors in the intact embryonic retina. Int Dev Neurosci 25:499-508.

Okada Y, Shimazaki T, Sobue G, Okano H (2004) Retinoic-acid-concentrationdependent acquisition of neural cell identity during in vitro differentiation of mouse embryonic stem cells. Dev Biol 275:124-142.

Okano H (2002) Stem cell biology of central nervous system. J Neurosci Res 69:698-707.

Okano H, Sawamoto K (2008) Neural stem cells: involvement in adult neurogenesis and CNS repair. Philos Trans R Soc Lond B Biol Sci 363:2111-21122.

Parras CM, Galli R, Britz O, Soares S, Galichet C, Battiste J, Johnson JE, Nakafuku M, Vescovi A, Guillemot F (2004) Mash1 specifies neurons and oligodendrocytes in the postnatal brain. EMBO J 23:4495-4505.

Pearson R, Catsicas M, Becker D, Mobbs P (2002) Purinergic and muscarinic modulation of the cell cycle and calcium signaling in the chick retinal ventricular zone. J Neurosci 22:7569-7579.

Ralevic V, Burnstock G (1998) Receptors for purines and pyrimidines. Pharmacol Rev 50:413-492.

Resende RR, Majumder P, Gomes KN, Britto LRG, Ulrich H (2007) P19 embryonal carcinoma cells as in vitro model for studying purinergic receptor expression and modulation of $N$-methyl-D-aspartate-glutamate and acetylcholine receptors during neuronal differentiation. Neuroscience 146:1169-1181.

Riquelme PA, Drapeau E, Doetsch F (2008) Brain micro-ecologies: neural stem cell niches in the adult mammalian brain. Philos Trans R Soc Lond B Biol Sci 363:123-137.

Sakaguchi M, Shingo T, Shimazaki T, Okano HJ, Shiwa M, Ishibashi S, Oguro H, Ninomiya M, Kadoya T, Horie H, Shibuya A, Mizusawa H, Poirier F, Nakauchi H, Sawamoto K, Okano H (2006) A carbohydrate-binding protein, Galectin-1, promotes proliferation of adult neural stem cells. Proc Natl Acad Sci U S A 103:7112-7117.

Schauwecker PE (2006) Genetic influence on neurogenesis in the dentate gyrus of two strains of adult mice. Brain Res 1120:83-92.

Shen Q, Goderie SK, Jin L, Karanth N, Sun Y, Abramova N, Vincent P, Pumiglia K, Temple S (2004) Endothelial cells stimulate self-renewal and expand neurogenesis of neural stem cells. Science 304:1338-1340.

Shen Q, Wang Y, Kokovay E, Lin G, Chuang SM, Goderie SK, Roysam B, Temple S (2008) Adult SVZ stem cells lie in a vascular niche: a quantitative analysis of niche cell-cell interactions. Cell Stem Cell 11:3:289-300.

Song H, Stevens CF, Gage FH (2002) Astroglia induce neurogenesis from adult neural stem cells. Nature 417:39-44.

Spradling A, Drummond-Barbosa D, Kai T (2001) Stem cells find their niche. Nature 414:98-104.

Sugioka M, Fukuda Y, Yamashita M (1996) $\mathrm{Ca}^{2+}$ responses to ATP via purinoceptors in the early embryonic chick retina. J Physiol 493:855-863.

Tavazoie M, Van der Veken L, Silva-Vargas V, Louissaint M, Colonna L, Zaidi B, Garcia-Verdugo JM, Doetsch F (2008) A specialized vascular niche for adult neural stem cells. Cell Stem Cell 3:279-288.

Weissman TA, Riquelme PA, Ivic L, Flint AC, Kriegstein AR (2004) Calcium waves propagate through radial glial cells and modulate proliferation in the developing neocortex. Neuron 43:647-661.

Yegutkin GG (2008) Nucleotide- and nucleoside-converting ectoenzymes: important modulators of purinergic signaling cascade. Biochim Biophys Acta 1783:673-694.

Zimmermann H (2006) Nucleotide signaling in nervous system development. Pflugers Arch 452:573-588. 